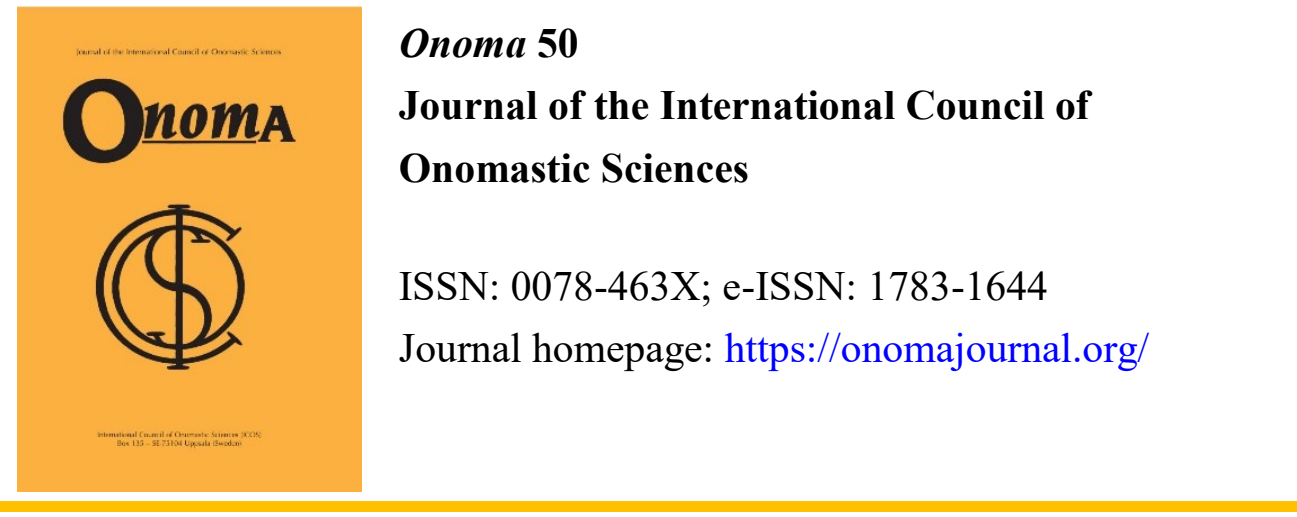

\title{
Identifying middle names in onomastic profiles - Exploring the usage of middle names in 19th century Denmark through the census of 1880
}

DOI: $10.34158 /$ ONOMA.50/2015/3

\author{
Lars-Jakob Harding Kallerød and Barbara Ana Revuelta-Eugercios \\ Lars-Jakob Harding Kællerød \\ Name Research \\ Department of Nordic Studies and Linguistics (NorS) \\ University of Copenhagen \\ Njalsgade 136 \\ DK-2300 Copenhagen S \\ jvw124@hum.ku.dk / 1.j.h.kaelleroed@gmail.com
}

Barbara Ana Revuelta-Eugercios

Research associate professor and archivist

Danish National Archives (Rigsarkivet)

Jernbanegade 36

DK-5000 Odense

bre@sa.dk

Associate Professor

Saxo Institute

University of Copenhagen

Karen Blixens Plads 8

DK-2300 Copenhagen S

barbara.revuelta@hum.ku.dk 
To cite this article: Kællerød, Lars-Jakob Harding \& Revuelta-Eugercios, Barbara Ana. 2015. Identifying middle names in onomastic profiles Exploring the usage of middle names in 19th century Denmark through the census of 1880. Onoma 50, 73-101. DOI: 10.34158/ONOMA.50/2015/3

To link to this article: https://doi.org/10.34158/ONOMA.50/2015/3

(C) Onoma and the authors.

Identifying middle names in onomastic profiles - Exploring the usage of middle names in 19th century Denmark through the census of 1880

Abstract: Middle names in Denmark have a long and varied history. Today, approximately one in three Danes has a middle name; until the 19th century, however, such names were used almost exclusively among the nobility, with lesser usage among the clergy and bourgeoisie. During the 19th century, Denmark underwent profound societal changes and saw the introduction of restrictive naming legislation. These may have had an impact on the increasing usage of middle names across a larger part of the population, which can be read out of a comparison of the names registered in the Danish censuses of 1787 and 1880.

This survey explores the changing usage of middle names during this period by analysing onomastic profiles as they occur in the Danish census of 1880, which records almost 2 million inhabitants of all ages. A methodology has been devised for identifying middle names which, with certain reservations, identifies the presence or absence of middle names in the onomastic profiles of approximately $98 \%$ of the individuals listed in the source, of which $6.2 \%$ are shown to bear a middle name. Quantitative analysis reveals large differences in usage of middle names across geography and various demographic criteria such as sex, age and relative urbanity, showing that middle names are used much more frequently among males and that frequency among both sexes increases markedly towards the end of the period under consideration. The potential forces behind these apparent disparities are discussed and some tentative conclusions drawn.

Keywords: Personal names, surname-typological middle names, systematic methodology, 19th century, Denmark.

\section{Identification des noms intermédiaires dans les profils onomastiques. Une étude sur l'utilisation des noms intermédiaires au Danemark au XIX ${ }^{\text {ème }}$ siècle à travers le recensement de 1880}

Résumé : Au Danemark, les noms intermédiaires ont une histoire longue et variée. Aujourd'hui, environ un Danois sur trois a un nom intermédiaire. Cependant, avant le XIX $^{\text {ème }}$ siècle, ces noms sont presque exclusivement utilisés par les nobles et d'un usage moins répandu parmi le clergé et la bourgeoisie. Au cours du $\mathrm{XIX}^{\text {ème }}$ siècle, le Danemark subit de profonds changements sociétaux en même temps que de nouvelles lois plus restrictives quant aux noms sont introduites. Ces lois peuvent avoir influencé la croissante popularité du nom intermédiaire dans la 
société danoise. Une comparaison des noms enregistrés lors des recensements de 1787 et 1880 confirme cette tendance.

Cette étude examine l'évolution de l'utilisation des noms intermédiaires au cours de cette période à travers une analyse des profils onomastiques dans le recensement danois de 1880 sur une population d'environ 2 millions d'habitants de tous âges. L'élaboration d'une méthodologie a permis de repérer les noms intermédiaires. À quelques exceptions près, cette démarche identifie la présence ou l'absence de noms intermédiaires dans les profils onomastiques d'environ $98 \%$ des individus répertoriés dans la source, dont $6,2 \%$ se sont avérés porter un nom intermédiaire. Une analyse quantitative montre d'importantes différences géographiques et démographiques dans l'utilisation des noms intermédiaires. Les noms intermédiaires sont beaucoup plus répandus parmi les hommes et la fréquence d'utilisation augmente nettement vers la fin de la période étudiée, à la fois chez les hommes et chez les femmes. Enfin, de possibles explications derrière ces différences sont discutées et des conclusions sont proposées.

Mots-clés : Noms de personnes, noms intermédiaires, méthodologie systématique, XIX ${ }^{\text {ème }}$ siècle, le Danemark.

\section{Die Identifizierung von Mittelnamen in onomastischen Profilen. Eine Erforschung des Gebrauchs von Mittelnamen im Dänemark des 19. Jahrhunderts anhand der Volkszählung von 1880}

Zusammenfassung: Mittelnamen haben in Dänemark eine lange und abwechslungsreiche Geschichte. Heute trägt etwa jeder dritte Däne einen Mittelnamen. Bis ins 19. Jahrhundert wurden diese Namen jedoch vorwiegend in Adelskreisen verwendet, während sie bei Klerus und Bürgertum weniger verbreitet waren. Während des 19. Jahrhunderts durchlief Dänemark tiefgreifende gesellschaftliche Veränderungen und ein restriktives Namensgesetz wurde eingeführt. Dieser Wandel könnte Einfluss gehabt haben auf die zunehmende Verwendung von Mittelnamen in breiteren Teilen der Bevölkerung, wie ein Vergleich der bei den dänischen Volkszählungen von 1787 und 1880 registrierten Namen zeigt.

Die Studie untersucht den sich wandelnden Gebrauch von Mittelnamen während dieser Periode, indem onomastische Profile zur Zeit der Volkszählung von 1880 analysiert werden, welche nahezu zwei Millionen Einwohner aller Altersgruppen erfasste. Es wurde eine Methode zur Identifizierung der Mittelnamen entwickelt, die mit gewissen Vorbehalten das Vorkommen oder Fehlen von Mittelnamen in den onomastischen Profilen von ca. 98\% aller in der Quelle gelisteten Personen umfasst. Es zeigt sich, dass 6,2\% einen Mittelnamen trugen. Eine quantitative Analyse zeigt große Unterschiede im Gebrauch von Mittelnamen, sowohl geographisch als auch in verschiedenen demographischen Aspekten wie Geschlecht, Alter und Verstädterung. Es zeigt sich, dass Mittelnamen viel häufiger bei Männern vorkommen und dass der Gebrauch bei beiden Geschlechtern zum Ende des Beobachtungszeitraums deutlich ansteigt. Die möglichen Gründe für diese evidenten Ungleichheiten werden diskutiert und vorläufige Schlussfolgerungen gezogen.

Schlüsselbegriffe: Personennamen, Mittelnamen, systematische Methodologie, 19. Jahrhundert, Dänemark. 


\title{
Identifying middle names in onomastic profiles - Exploring the usage of middle names in the 19th century Denmark through the census of $\mathbf{1 8 8 0}^{1}$
}

\author{
LARS-JAKOB HARDING KÆLLERøD AND \\ BARBARA ANA REVUELTA-EUGERCIOS
}

\section{Introduction}

A traveller journeying through Denmark in the second half of the 18th century, making acquaintance with people from different regions of the country, would notice naming patterns amongst the population that were largely homogeneous. This is evident from the Danish census of 1787, where the vast majority of the population across the country is registered with just one first name and a patronymic consisting of their father's forename and the suffix -søn/-sen ('son') or -datter ('daughter'), e.g. Hans Jensøn, Søren Larsen and Ane Nielsdatter (Kællerød 2017b: 118).

By contrast, only a century later, a similar traveller would encounter a much more diverse naming practice, exemplified by names from the Danish census of 1880. In the island of Mors, in the north-western part of Jutland, she might meet a farmer with the name Peder Kristensen Fruesgaard; in the southern part of the mainland she might encounter a gardener named Peder Nissen Hansen. On the major islands she would more likely find people with names like Hans Jokumsen and Bodil Kjerstine Jensen (a farmer couple from Funen) or Anders Jensen and Ellen Magrete Andersen (a worker from Zealand and his wife). In the capital, Copenhagen, she might chance on a boy named Ove Conrad Ludolph Holbøll Fog, while in the most eastern part of the country, on the island of Bornholm, she could meet a joiner called Peder Kofod Pedersen.

The major noticeable difference between the two timeframes is the increased prevalence of middle names. Note here that in Danish onomastics, the term 'middle name' refers to something more specific than the name's position within the full onomastic profile (first name(s), (middle name(s)) and surname): to qualify as a 'middle name', irrespective of typological form, that component must be capable of use as a surname (such as Kristensen in Peder

\footnotetext{
We are grateful for the constructive criticism of the manuscript provided by Chris Young, Glasgow.
} 
Kristensen Fruesgaard); by contrast the Kjerstine in Bodil Kjerstine Jensen can only function as a (here second or subsidiary) first name. Some names are ambiguous in character due to their currency as both first names and surnames, such as Conrad and Ludolph in Ove Conrad Ludolph Holbøll Fog.

It is in the 19th century that we find the seeds of modern Danish naming practice, and today approximately a third of the Danish population has a middle name (Kællerød 2017a: 95 f.) However, until an ongoing project by Kællerød (2015), the Danish middle name had not been the focus of any systematic study. The source for this study is the Danish census of 1880, which facilitates analysis of the period in which naming practice evolved most significantly. Once onomastic components have been characterised as middle names (in the census, each individual's full onomastic profile is listed in one field), they can be collated with respect to geographical distribution, family composition and socio-demographics, and an insight in the usage of middle names can be obtained.

The process of identifying middle names can be greatly accelerated by use of information technology tools. Building on Kællerød's current $\mathrm{PhD}$ project (2015) and the work of Revuelta-Eugercios in linking individuals across censuses (in press), a program was developed to identify and extract middle names, or note their absence, for approximately $98 \%$ of the almost 2 million individuals listed in the 1880 census.

\section{The usage of middle names ${ }^{2}$}

The term mellemnavn ('middle name') is relatively new. The first instance occurs as late as 1960 in the report Betcenkning om en ny lovgivning om personnavne [Report on a new Legislation on Personal Names] (BLP), which proposed changes to the law on permissible names. The prevailing legislation (dating back to 1904) protected certain family names from being acquired as common surnames, requiring any prospective name-holder (unless they could demonstrate the pertinent genealogical pedigree) to obtain the unanimous consent of the family already bearing that name; the report identified the problematic phenomenon of such a family name being given, unhindered, as a 'middle name' (BLP 1960: 17; cf.: 33). For everyday purposes, such a middle name could be used as that person's surname. The resulting new legislation tightened the rules, allowing only names held by

2 An introduction to the middle name, the usage of names that resemble middle names in an historical perspective, and a presentation of the profound changes and the name regulations in the 19th century believed to have had an important impact on the increased distribution of middle names has previously been given in Danish in Kællerød 2017a and 2017b. 
parents or grandparents to be passed on as middle names (LP 1961: Chapter 3, section 14; cf. Chapter 1; Section 8, No. 1).

The first time the term mellemnavn was used in an academic context in Denmark was in 1965, when Meldgaard (1965: 115 ff.) gave examples of middle names in an appendix to her study of name usage in a rural district of Jutland. However, it was not until NORNA's (Nordiska samarbetskommittén för namnforskning [The Nordic cooperative committee for onomastic research]) 1981 symposium (held in Lund) on the terminology of personal names that a 'middle name' was defined as: “...the or those name(s) in an individual's full name, that appear(s) after the last first name and before the surname. The middle name must be surname-typological"3 (Hjorth Pedersen 1983: 84). That definition is, however, not without issues. The onomastic profile Niels Bentzen Marius Hansen, for example, contains as its second component a patronymic followed by, as its third component, what appears to be a first name: how are these two elements best characterised? In the context of the first two components representing the first name and surname of a relative, it might be simplest to regard the second component, albeit a surname in origin, as a specific sort of second first name; however, there is insufficient data to corroborate this hypothetical interpretation in all cases (cf. Kousgård Sørensen 1984: 108 ff.; 1997: 45 ff.).

The difficulties of defining the middle name are reflected in the report Personnavne. Betoenkning afgivet af Navnelovsudvalget [Personal Names. Report submitted by the Committee of Acts of Names] (PBN) from 2004, which led to the most recent naming legislation (N 2006) which came into force in 2006. In the report, it is stated that: "Middle names generally have the character of a surname, but they are placed after the first name and before the surname. In practice, however, the character of middle names is unclear in certain regards"4 (PBN 2004: 44). Jørgensen (2013: 13), addressing this fuzziness, asserts that middle names are determined by their position in the onomastic profile (between first name(s) and the surname), while they typologically are either first names or surnames. According to Danish law a person can have only one surname; hence the term middle name is necessary for administrative purposes, albeit problematic for research purposes.

3 Freely translated from the original Danish: ...det eller de navne $i$ en persons navn, der står efter det sidste fornavn og før efternavnet. Mellemnavnet skal vare slagtsnavnetypologisk.

4 Freely translated from the original Danish: Mellemnavne har i almindelighed karakter af et efternavn, men placeres efter fornavnet og inden efternavnet. I praksis er karakteren af mellemnavne imidlertid på visse punkter uklar. 


\subsection{The usage of what resemble middle names - an historical perspective}

Although the evolution of what we now call middle names was most significant during the 19th century, the origins stretch back further into history. From the Middle Ages there is evidence of personal names such as Poeter Palnisun Hwitce (c. 1200) $)^{5}$, Johan Peterssøn Troethere (1313) and the brothers Eric Iwerssøn Lykke and Iønes Iwerssøn Lykke (1400) ${ }^{6}$, where a patronymic appears between the first name and an informal byname. However, this type of name structure in the Middle Ages is rare, or at least rarely recorded, and not used consistently (Jørgensen 2013: 14).

During the Middle Ages it became custom among noble families to adopt permanent family names. In 1526 King Frederik I of Denmark directed this practice to become mandatory for the nobility; those who bore the same coat of arms were to take the same name (Vogt 2005: 383). Patronymics were often retained as additional names, greatly resembling modern middle names, such as in Mogens Axelsen Gøye (1411-1450), Beate Clausdatter Bille (1526-1606) and Henrik Knudsen Gyldenstjerne (1540-1592). This pattern of naming soon began to be adopted among the clergy and bourgeoisie: for example the historian Anders Sørensen Vedel (1542-1616), son of Søren Sørensen, had several children bearing names such as Marine Andersdatter Vedel and Lauge Andersen Vedel. A new phenomenon emerged in 1671 with the creation of the aristocratic ranks of count and baron: daughters of these noblemen, upon marriage into a similarly ennobled family, were to combine their own family name with that of their spouse; neither of these family name components would be a patronymic (Jørgensen 2013: $15 \mathrm{ff}$.).

In the broader population, both fixed surnames and middle names were practically unknown until the 19th century. Farmers, fishermen and servants retained more traditional naming conventions, typically one first name followed by a patronymic and/or an unofficial byname used locally to distinguish individuals within a community (Kisbye 1979: 83; 1981: 125 f.). As first names were often determined by commemorating ancestors (paternal grandfather, maternal grandfather, paternal grandmother, maternal grandmother), while a patronymic by definition identifies an individual as someone's son or daughter, traditional naming practice is dominated by placing the individual within the context of their close family. It is unlikely, however, that the population at the time considered the patronymics themselves to be names rather than descriptors. While legislative reforms in the 19th century (discussed below) imposed a fixed surname, and many

5 Pater Palnisun Hwitce is mentioned in the so-called Broderliste ('Brother list') in the Danish book of land taxations, Kong Valdemars Jordebog (KVJb: 84, 164 and 55r).

6 Johan Peterssøn Trathere, Eric Iwerssøn Lykke and Iønes Iwerssøn Lykke are all mentioned in medieval diplomas (DiplDan). 
patronymics began to function as surnames, it does not follow that reality and perception were always in step with each other over the period of transition. As far as first names are concerned, the conservative recycling of names within families went hand in hand with relative consistency across geography, as illustrated by Eggert (2009) in an investigation of the use of first names among the Danish population in the census from 1801/03: at this point more than $50 \%$ of the entire population carry one of just seven names as their first name, namely the female names Anne, Marie and Karen and the male names Peder, Hans, Jens and Niels, these latter four forming the basis of the most common patronymics.

\subsection{Name regulations and new realities}

During the 18th and 19th century, a number of regulations concerning naming practice were issued in Denmark, and it is almost certain that this had a significant impact on the use of middle names. The process started not in the Kingdom of Denmark proper but in the separately administered Duchy of Schleswig-Holstein. Here, in 1771, the authorities established the principle of fixed surnames for all inhabitants. It was argued that the tradition of patronymics provided difficulties in legal matters such as inheritance cases (Pedersen 2001: 203). There is no reason to believe that the administrative challenges were any less within the Kingdom of Denmark itself. Nevertheless, it would be more than fifty years before similar regulations were ordered there. Prior to the legislation, it had been normal to baptize children with only first names, which practice is reflected in church records where only first names of children are listed, while parents and godparents are listed with first name and patronymic or family name. In $1828 \mathrm{King}$ Frederik VI ordered that the entire population of Denmark should adopt fixed surnames: children should not only be given a first name but also a family name (Dåbsforordningen 1828: §18). The letter of the law was somewhat unclear as, although it established that a family name should be given when a child was baptized, it did not indicate who could decide on the name and what names might be appropriate (Pedersen 2001: 204). That led to a series of official clarifications: it was for the father to decide whether to give his child either a patronymic derived from his own first name, his (the father's) own byname, or a name relating to a place to which he (the father) belonged; all siblings were to have the exact same family name, meaning that girls could no longer be given patronymics with the suffix -datter ('daughter') (Degn 2001: 17; cf. Pedersen 2001: 204).

These legal interventions were clearly in conflict with both traditional naming practices and individual freedoms, affecting the identity of both name 
receiver and name giver. Despite these strictures, in many places traditional patronymics persisted largely as before. The options allowed for family names were interpreted by many as representing a choice, which each father would be able to exercise afresh in every generation (Pedersen 2001: $204 \mathrm{f}$.). As a result of this, new legislation was drawn up in 1856 , which explicitly stated that family names chosen after the regulations in 1828 were to function patrilineally, passing unchanged to all subsequent generations (Degn 2001: 18).

From these possibly wilful misinterpretations of the 1828 regulations, it is reasonable to assume a considerable level of cultural, if not emotional, attachment to traditional naming practices. Analysis of the 1880 census (discussed in more detail below) reveals that approximately $7.7 \%$ of children age $0-5$, born in the years $1875-80$, are listed with middle names; the corresponding figure is a consistent $5.6-5.9 \%$ for previous generations (born prior to 1861) (cf. Table 6 below). Middle names may have been regarded as a way to maintain something similar to traditional naming practices while complying with the new legislation: while surnames were fixed, middle names could change with each generation to reflect the family relationships each name giver wished to commemorate, including patronymics.

Preliminary analysis indicates regional variation in middle name usage: in the parish of Frøslev on the island of Mors a quarter of the inhabitants are listed with middle names in the 1880 census, while less than one percent of the inhabitants of Engestofte on Lolland in the southern part of Denmark are listed with a middle name (Kællerød 2017a; cf. Kællerød 2018a). Another aspect to be aware of is cultural differences between the regions: the Jutland peninsula, the island of Zealand (where Copenhagen is located) and the smaller islands in between all had different economic and demographic characteristics as well as diverse social customs (Matthiesen 1985; Johansen 2004). Such diversity may have led to distinct naming practices and influenced local reactions to the regulations.

The ascendance of middle names in the 19th century, albeit in part a response to legislation, might also be attributed to societal changes, some of which may themselves be considered drivers of the legislation. Agricultural reforms, military defeats (losing Norway in 1814 and Schleswig-Holstein in 1864) and movements towards industrialisation and urbanisation all made an impact in terms of both practicalities and how Danes viewed themselves and their collective identity, contributing to a rise in 'Danishism' (Kællerød 2017b: 120; Feldbæk 1991: 255 f.). On a practical level, the need for individuals to be uniquely identified became more important when people started moving about the country, particularly to larger cities where the commonplace nature of traditional names could cause both confusion and effective anonymity for many, especially those with a patronymic as a family name (Kisbye 1979: 84). One way to stand out from the masses, as Kisbye 
suggests (1981: $130 \mathrm{f}$.), might be to adopt a relatively distinctive name as a middle name.

\section{Data and methods: Studying middle names from census material}

Among the many historical sources that include names, some of the most useful for research purposes are administrative documents or records from compulsory statistical or administrative exercises such as censuses. While church records provide what may be regarded as official names, a census offers a snapshot of names which is likely to represent more closely what individuals have regarded as their name as used. However, it must be emphasised that very little is known about exactly how information was given to the scribes of the censuses, and how uniform the practices were from parish to parish. Although censuses are vulnerable to a number of errors (some information may not be correct and it is possible that individuals or even entire households have been left out), they are in many ways the best sources we have for studying naming patterns according to various attributes (sex, age, marital status, etc.) across the entire population of a wide (and finely granulated) geographical area.

This article takes advantage of the large-scale crowdsourcing project coordinated by Rigsarkivet (Danish National Archives) leading to the creation of Dansk Demografisk Database ('Danish Demographic Database') (DDD), which contains, among other sources, seven transcribed censuses of the 18th and 19th century ${ }^{7}$. The project started in 1992 as the KildeIndtastningsProjektet ('Source Entry Project'), a collaboration between historians, genealogists and Dansk Dataarkiv (now a part of Danish National Archives) to coordinate the transcription of sources such as censuses, church records and a number of minor sources for genealogy and research use. Since then, working on a voluntary basis, members of the genealogist community have executed the transcription and also developed data entry software. The main principle is to keep the transcriptions true to the source by typing everything exactly as it appeared in the original, which makes this material suitable for research purposes (Clausen 2015). Today, despite the richness and availability of this material, it has only been used by a few authors for name research and mainly for examinations of the use of first names (e.g. Eggert 2008; 2009; Kællerød 2018b).

As mentioned initially, the main source for the present study is the 1880 census (C1880) - in which almost 2 million inhabitants in the Kingdom

7 The censuses from 1787, 1801/03, 1834, 1840, 1845, 1850 and 1880 are all accessible at the website http://ddd.dda.dk/. Be aware that none of the censuses have been fully proofread yet. 
of Denmark (excluding the Faroe Islands, Greenland and Iceland) are registered - as it appears in DDD. It contains the names of surviving individuals born from approximately 1800 to 1880 and provides evidence of changes in name patterns throughout this period. Note, however, that the data do not provide conclusive proof of changes over time: people have fluid relationships with their names; the name that an individual reported in 1880 may not necessarily be exactly the same name he or she had been given at baptism. Moreover, marriage, relocation, occupation and other factors may have had an impact on what individuals regarded as their name, or deemed appropriate to report as their name, for the purpose of the census. Age constitutes a key determinant in the present analysis but it is to be considered in combination with other recorded variables such as sex, marital status, origin, and occupation.

Although the transcriptions are largely true to the original sources, full adherence to the transcription rules and best practice cannot be guaranteed. This has consequences for how easy it is to work with the resulting data, particularly affecting names. In the database, the full onomastic profile of a person appears in one single field, reflecting the appearance under the caption navn ('name') of the original census sheet. However, not only names are recorded in these fields as they often contain additional information such as maiden names, e.g. født Hansen ('born Hansen'), honorifics, titles or markers of status, including fru ('Mrs.'), frøken ('Miss') and enke ('widow'), and references to other members of the family, for example enke efter ('widow after') and gift med ('married to'). There were neither a manual parsing of the components (first name(s), middle name(s), surname) of the onomastic profile at the time of transcription nor a categorisation of the additional information. Similarly, no special flagging was used when names were replaced by expressions that designated infants and children, such as barn ('child'), drengebarn ('baby boy') and udøbt barn ('unbaptized child'). Occasionally, the field designed for an individual's name is filled instead with the description of an unoccupied dwelling, shop or workshop.

Difficulties aside, the transcription process has presented the data in usable form, even if substantial pre-processing is required. For the main social and demographic variables, the standardised and codified variables developed beforehand within the context of the Copenhagen Historical Population Database have been used (Revuelta-Eugercios 2016). As mentioned previously, the additional processing of names builds on the name identification techniques and linking techniques developed by Revuelta-Eugercios (in press) combined with insights into middle name usage from Kællerød's ongoing research project (2015). The strategy to extract middle names from the full onomastic profiles (or rather any text recorded in the census within that field) involved four steps, which will be discussed in turn below: 
84 LARS-JAKOB HARDING KÆLLERøD AND BARBARA ANA REVUELTA-EUGERCIOS

i. Parsing the text to remove unwanted characters, titles, etc., leaving full onomastic profiles consisting of name components only.

ii. Developing a classification table to identify the typology of each single name component in an onomastic profile.

iii. Extracting the surname and first name(s) from the full name field.

iv. Identifying those full onomastic profiles that contain (a) middle name(s).

\subsection{Cleaning and parsing}

From the original file of the census that contained 1,967,947 records, 11,328 were discarded as corresponding not to named individuals but to e.g. places, shops and unnamed children (often listed as udøbt barn ('unbaptized child'). The remaining records were purged of problematic markings and characters such as question marks, dots or double spaces. Hyphens, where present, were interpreted as joining sub-elements of a name within the same name component, e.g. Paludan-Müller. When names contained prepositions such as de, la, van and von, artificial hyphens were created to keep the subelements together within the same component, e.g. de-Neergaard and vanAcker. Superfluous maiden names were extracted by isolating all characters to the right of the expressions født or $f$. ('born') in separate fields that has not been used for the present analysis. The resulting full onomastic profile (a term here referring to the field entries as cleaned and edited) comprises the first name(s), possible middle name(s) and the surname of the relevant individual. Each full onomastic profile was then parsed to isolate each of its name components such that the registration Anne Katrine Pedersen Holm født Hansen would be parsed into four name components: Anne, Katrine, Pedersen and Holm.

\subsection{Classification of name components}

Before assigning a definitive categorisation for the individual name components within any full onomastic profile as first name, middle name or surname, it was necessary to establish the typology of each field entry, i.e. every name component within the Danish onomasticon. In the example Anne Katrine Pedersen Holm, Anne and Katrine are readily classified as first names only; Pedersen is a patronymic in form; Holm is a known family name.

55,418 distinct examples (or spellings) of name components were extracted from C1880, which figure excludes initials and abbreviations. These names were classified separately according to the sex of the namebearer: for example, the name component Adolf, when borne by a man, could 
be typologically either a first name or a family name; when borne by a woman, Adolf can only be a family name. Allowing for abbreviations, initials, and separate treatment by sex, 123,294 generalised typological classifications have been made, each element being classed as one of the following: 'male [first] name', 'female [first] name', 'unisex [first] name', 'initial', 'abbreviation', 'patronymic', 'family name', 'female [first] name and family name', 'male [first] name and family name', 'unisex [first] name and family name', or, in a few cases, 'unknown'.

As a starting point in this process of classification, use was made of various research databases. In Dødsattester, København ('Death Certificates, Copenhagen') for the years 1880-1882 (cf. Revuelta-Eugercios \& Løkke in press) and Det Danske Udvandrerarkiv ('Migration Records in Denmark') (DDU), 1880-1918, the division of first names, middle names and surnames from historical sources had been performed manually. Insights were gained from more contemporary name usage as presented in Danskernes Navne ('The Names of the Danes'), which contains name information of the approximately 6.5 million Danes registered in the Civil Registration System, CPR, since this was established in 1967 and up to 2005. These preliminary classifications were augmented and revised manually to produce a nearcomprehensive 'typology table', with particular attention paid to any name component appearing 25 times or more within C1880 (equating to 5,700 classifications, accounting for $93.4 \%$ of the 5,300,939 naming instances).

\subsection{Parsing onomastic profiles into first names and surnames}

In most records, the surname presented as the last name in the full onomastic profile (as cleaned); however, since there were exceptions, it was not possible to automatically identify the last name as the surname. Occasionally, the positions of the surname and first name were inverted, and a number of individuals $(18,266$, mostly women and children) were listed without a surname and only a first name. Such records were eliminated and only when a last name in a full profile corresponded typologically to either a family name or a patronymic $(1,817,382$ records) it was regarded as a surname. Combined, these two scenarios accounted for 1,835,648 (93.8\%) of the $1,956,619$ registered individuals. In the remaining cases, where the typology of the last name component could not be determined, two working assumptions were made according to known patterns of name composition:

i. In an onomastic profile containing three names, where the second position was occupied by a patronymic, the third name component was assumed to be a surname. This assumption was applied in 19,491 cases, increasing coverage to $94,81 \%$. 
86 LARS-JAKOB HARDING KÆLLERøD AND BARBARA ANA REVUELTA-EUGERCIOS

ii. The last component in an onomastic profile was assumed to be a surname in cases where: (a) the full onomastic profile contained three or more name components; (b) the first name component was by typology a first name; (c) the last name component was typologically not a first name (but rather a patronymic, a family name or unknown); and, because small children relatively often are not listed with a name, (d) the relevant individual should be more than five years old. This assumption enabled the attribution of a further 71,042 surnames, with a tolerable degree, which with certain reservations increased the coverage to $98.4 \% \quad(1,926,181$ individuals).

Beyond this point, any additional rules or assumptions would apply only in very small subsets of the remaining records. The outstanding 30,484 records were excluded to leave a data set relating to 1,926,181 identified individuals as the basis for subsequent analysis.

\subsection{Identifying profiles which contain a middle name}

By definition, only those full onomastic profiles containing three or more name components $(57.2 \%$ of the total) have the potential to contain a middle name. The final task was to determine in each case whether a name component in medial position was best characterised as a secondary first name or a middle name.

In all cases, analysis began with the penultimate name component, that immediately preceding the surname. To be considered as a middle name, this component had to correspond to a typology of a patronymic or a family name. In the full onomastic profile, Jens Dalsgaard Justesen, Dalsgaard is in origin a farm name and has been classed as a family name; in Anne Katrine Pedersen Holm, Pedersen is classed as a patronymic: both of these can be characterised unambiguously as middle names. 
Table 1: The typology of name components in penultimate position. When the typology corresponds to either a patronymic or a family name, the name component is regarded as a middle name. A number of name components are categorised as 'both male name and family name' or 'both female name and family name', and these have been classified as middle names when they appear in onomastic profiles of individuals whose sex is given as opposite to the gender of which the name in question might function as a first name. 'Unclassified first name/Family name' covers a group of name components where it has yet not been possible to make a differentiation of the gender of which the name can function as a first name, while 'Not coded' covers the name components that could not be identified.

\begin{tabular}{|l|r|r|r|r|r|}
\hline $\begin{array}{l}\text { Penultimate name } \\
\text { component }\end{array}$ & \multicolumn{1}{|c|}{$\begin{array}{c}\text { Middle } \\
\text { name }\end{array}$} & $\begin{array}{c}\text { Potential } \\
\text { middle } \\
\text { name }\end{array}$ & \multicolumn{1}{c|}{$\begin{array}{c}\text { No } \\
\text { middle } \\
\text { name }\end{array}$} & Unknown & Total \\
\hline First name & - & - & 937,891 & - & 937,891 \\
\hline Patronymic & 92,100 & - & - & - & 92,100 \\
\hline Family name & 27,151 & - & - & - & 27,151 \\
\hline $\begin{array}{l}\text { Female first name/ } \\
\text { Family name }\end{array}$ & 32 & 79 & - & - & 111 \\
\hline $\begin{array}{l}\text { Male first name/ } \\
\text { Family name }\end{array}$ & 107 & 13,494 & - & - & 13,601 \\
\hline $\begin{array}{l}\text { Unclassified first } \\
\text { name/ Family name }\end{array}$ & - & 3,503 & - & - & 3,503 \\
\hline$<3$ name components & - & - & 825,272 & - & 825,272 \\
\hline Not a name & - & - & 545 & - & 545 \\
\hline Not coded & - & - & - & 26,007 & 26,007 \\
\hline Total & $\mathbf{1 1 9 , 3 9 0}$ & $\mathbf{1 7 , 0 7 6}$ & $\mathbf{1 , 7 6 3 , 7 0 8}$ & $\mathbf{2 6 , 0 0 7}$ & $\mathbf{1 , 9 2 6 , 1 8 1}$ \\
\hline
\end{tabular}

This process resulted in an initial 119,251 positive identifications as middle names for patronymics and known family names (see Table 1). A further 139 instances of a middle name were ascertained by reference to the name-bearer's sex, to clarify some (but not all) examples of ambiguous typology, where names such as Holger can be either a family name or a male-only first name (and others, such as Øllegaard, a family name or a female-only first name). In the female profile Anne Marie Holger Knudsen, Holger cannot be a first name so must be a middle name. However, in Jens Holger Hjorth, the ambiguity persists: thus, a category of 'potential middle names' was created, numbering 17,076 naming instances. These names are problematic as only through further examinations of the use of Holger among name components borne by relatives (i.e. family members and godparents) can it be clarified whether Holger in Jens Holger Hjorth is used as a middle name. However, such an examination is beyond the scope of this article.

Middle names, or potential middle names, do occasionally appear earlier than in penultimate position. In the onomastic profile Herman Jensen Juul Bang Lauritsen, all three name components in medial position can be defined as middle names: Jensen is patronymic, while both Juul and Bang are 
common family names, albeit both rarely being used as male first names. More complicated are those onomastic profiles where a patronymic or a family name is followed by a name component with the typology of a first name such as Niels Bentzen Marius Hansen. As mentioned in chapter 2, the patronymic might in this case best be classified as a specific sort of secondary first name. However, these types of onomastic profiles do not occur often, and have therefore been left out of the further analysis, as different approach on these onomastic profiles are required.

\section{Who had middle names?}

In total, name components in penultimate position for 119,390 Danes registered in C1880 can with certain reservations be recognised as middle names, accounting for $6.2 \%$ of the $1,926,181$ identified individuals in the source. Inevitably, some nuances are lost with the methodological approach; a number of middle names are possibly left out, and some name components may mistakenly be identified as a middle name. Also, middle names occurring earlier in an onomastic profile than the penultimate position have for these analyses been left out. Nonetheless, the methods give an appropriate indication of the use of middle names on a nationwide level in the period investigated.

This figure may seem low, but taking into consideration that middle names prior to the 19th century were used almost exclusively in sections of the upper class, a frequency of $6.2 \%$ is a clear sign of changing naming patterns. For a greater insight into these changes, further examinations involving geographical and demographical parameters have been conducted for the 119,390 records containing middle names, which will be presented in the following subsections.

\subsection{Regional differences in middle name usage}

The regional distribution of middle names shows a substantially higher proportion of individuals listed with middle names in the Jutland peninsula than that found on the island of Zealand (Figure 1). These numbers support the considerable heterogeneity relative to geographical distribution found in pilot studies of middle names in C1880 covering selected towns and rural parishes (Kællerød 2017a; 2017b). Changes in naming patterns are often believed to follow the pattern of a stone skipping across water; spreading from metropolis to other towns (the consecutive points where the stone hits the water) and from there, like waves, to the villages and more rural areas (e.g. Meldgaard 1993: 66; cf. about dialectology in Chambers \& Trudgill 1998: 166). Therefore, this distribution is rather unexpected as the Danish 
capital, Copenhagen, is located on Zealand. 3.3\% of the individuals in Copenhagen County are listed with middle names, and though that is a higher frequency than found elsewhere on Zealand, the frequency is lower than that found in all counties outside Zealand.

A cursory examination of the length of full onomastic profiles reveals little or no connection between the number of name components in full onomastic profiles and the use of middle names. On the contrary, on Zealand, where a lower frequency of middle names is found, a slightly higher proportion of individuals are listed with three or more name components than is generally found in areas with a higher occurrence of middle names.

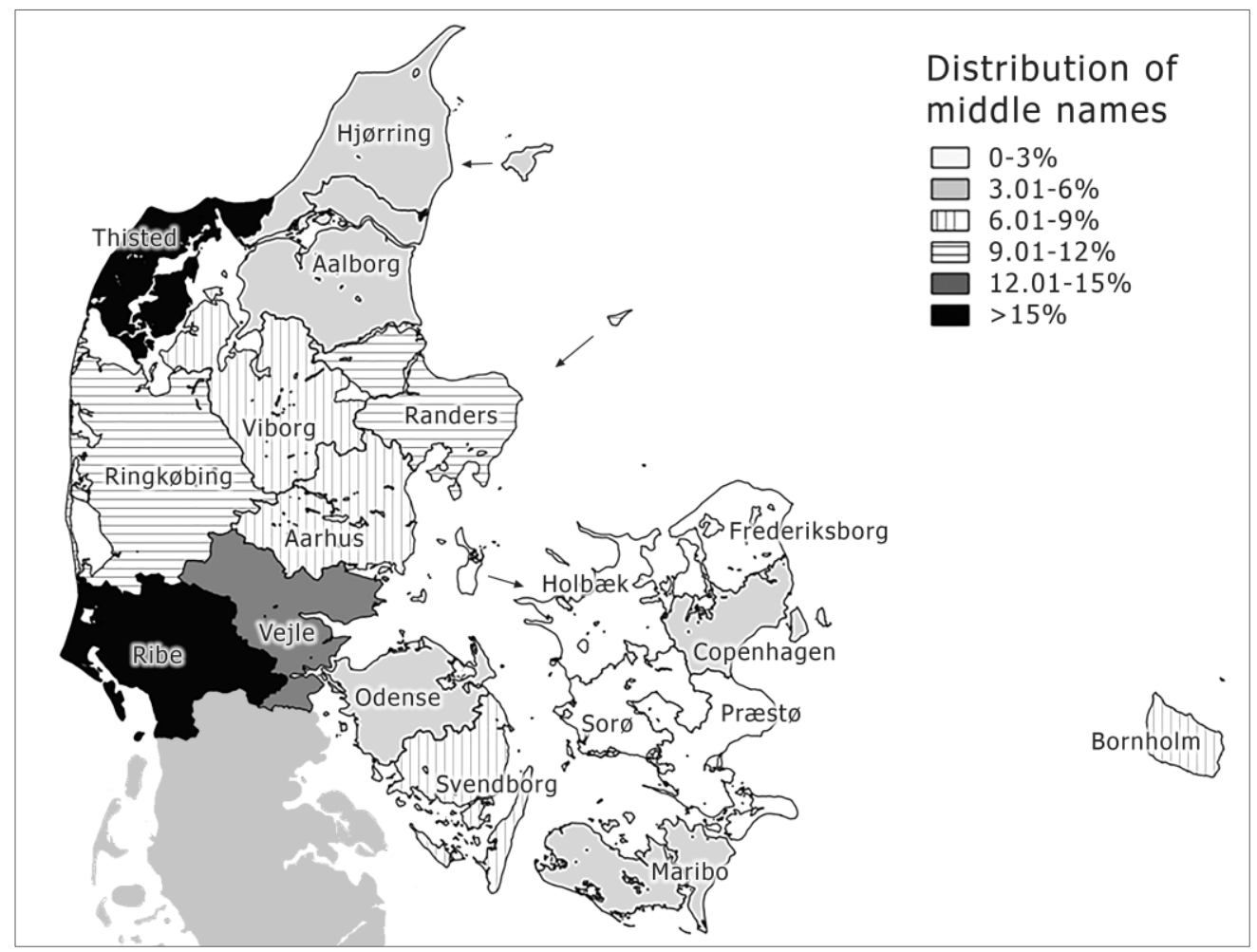

Figure 1: The distribution of middle names in C1880 in the Danish counties. The map shows a high concentration of middle names in the Jutland peninsula. In general, middle names are more frequent in Jutland, however, the distribution is extremely heterogeneous: in the northernmost county, Hjørring, $4.7 \%$ of the population have a middle name, while this figure is more than $15 \%$ in the counties of Ribe and Thisted. On the islands Funen (Odense and Svendborg), Lolland-Falster (Maribo) and Bornholm, between 3.6\% and 8.7\% are listed with middle names. On the island of Zealand where the Danish capital Copenhagen is located, the frequency of middle names is surprisingly low.

This geographical spread suggests a more integrated usage of middle names, and therefore perhaps a longer tradition of naming with such names, 
in certain areas. However, additional analysis shows that it may not be that simple. Five selected rural parishes from each of the five counties with the highest percentage of middle names in $\mathrm{C} 1880$ have been examined for middle names in the census from 1787 (C1787), the first Danish census containing names. ${ }^{8}$ In $\mathrm{C} 1880$, between $23.8 \%$ and $34.5 \%$ of the individuals in these parishes were listed with middle names; but in C1787 not a single middle name was found in four of the parishes, while in Engbjerg in Ringkøbing County only 2 of the 115 people registered (1.7\%) are listed with middle names. The low figures in 1787 suggest that middle names gradually became more frequent through the 19th century across the entire country.

Table 2: The percentage of middle names among residents in urban and rural parishes in each county in 1880. An urban parish is here defined as either a købstad ('town') or a handelsplads ('trading place'), although such often contain rural areas as well.

\begin{tabular}{|c|c|c|c|c|c|}
\hline County & Region & $\begin{array}{c}\text { Population } \\
\text { in urban } \\
\text { parishes }\end{array}$ & $\begin{array}{l}\text { Middle } \\
\text { names in } \\
\text { urban } \\
\text { parishes }\end{array}$ & $\begin{array}{c}\text { Middle } \\
\text { names in } \\
\text { rural } \\
\text { parishes }\end{array}$ & $\begin{array}{l}\text { Middle } \\
\text { names }\end{array}$ \\
\hline Aalborg & Jutland & $18.1 \%$ & $5.3 \%$ & $5.2 \%$ & $5.2 \%$ \\
\hline Aarhus & Jutland & $30.1 \%$ & $5.5 \%$ & $7.8 \%$ & $7.1 \%$ \\
\hline Bornholm & Bornholm & $36.8 \%$ & $7.1 \%$ & $6.6 \%$ & $6.8 \%$ \\
\hline Copenhagen & Zealand & $76.6 \%$ & $3.6 \%$ & $2.3 \%$ & $3.3 \%$ \\
\hline Frederiksborg & Zealand & $17.1 \%$ & $2.8 \%$ & $2.1 \%$ & $2.2 \%$ \\
\hline Hjørring & Jutland & $10.4 \%$ & $6.8 \%$ & $4.5 \%$ & $4.7 \%$ \\
\hline Holbæk & Zealand & $8.5 \%$ & $2.5 \%$ & $1.9 \%$ & $2.0 \%$ \\
\hline Maribo & $\begin{array}{l}\text { Lolland- } \\
\text { Falster }\end{array}$ & $19.2 \%$ & $3.3 \%$ & $3.7 \%$ & $3.6 \%$ \\
\hline Odense & Funen & $23.6 \%$ & $4.6 \%$ & $3.8 \%$ & $4.0 \%$ \\
\hline Præstø & Zealand & $11.0 \%$ & $3.1 \%$ & $2.1 \%$ & $2.2 \%$ \\
\hline Randers & Jutland & $17.5 \%$ & $7.1 \%$ & $11.5 \%$ & $10.7 \%$ \\
\hline Ribe & Jutland & $10.0 \%$ & $11.8 \%$ & $16.0 \%$ & $15.6 \%$ \\
\hline Ringkøbing & Jutland & $7.0 \%$ & $10.4 \%$ & $9.9 \%$ & $10.0 \%$ \\
\hline Sorø & Zealand & $17.6 \%$ & $3.2 \%$ & $1.4 \%$ & $1.7 \%$ \\
\hline Svendborg & Funen & $20.0 \%$ & $8.8 \%$ & $8.6 \%$ & $8.7 \%$ \\
\hline Thisted & Jutland & $10.7 \%$ & $10.1 \%$ & $15.8 \%$ & $15.2 \%$ \\
\hline Vejle & Jutland & $20.1 \%$ & $8.3 \%$ & $14.3 \%$ & $13.1 \%$ \\
\hline Viborg & Jutland & $10.8 \%$ & $7.5 \%$ & $6.8 \%$ & $6.9 \%$ \\
\hline Denmark & & $14.4 \%$ & $4.8 \%$ & $6.7 \%$ & $6.2 \%$ \\
\hline
\end{tabular}

As middle names can vary from generation to generation, the adoption of this type of name in the 19th century could possibly be the consequence of

8 The parishes Folding (Ribe County), Hammelev (Randers), Ljørslev (Thisted), Skærup (Vejle) and Engbjerg (Ringkøbing) were examined manually for middle names using the facsimiles available from AO. 
a reaction to the name regulation in those parts of society where traditional naming patterns dominated prior to legislation (e.g. peasants, fishermen, servants). Consequently, a higher frequency of middle names might be expected in the rural areas, which partly can explain the higher concentration in Jutland. However, there seems to be no clear relationship between the usage of middle names and the percentage of urbanisation in the counties (Table 2). Those counties on Zealand where the distribution of middle names is remarkably lower than in Jutland are in general no more urban than counties on the peninsula; Holbæk (8,5\%) and Præstø (11\%) are even less urban than most counties in Jutland, Funen and Bornholm. Jutland's counties Ribe and Thisted, where the distribution of middle names is highest (approximately 15\%), are both among the least urban counties as approximately $10 \%$ of the population here resides in urban parishes. However, Ringkøbing, where $10 \%$ are listed with middle names, is the county with the lowest share of urban residents (7.0\%), while Hjørring, where the lowest frequency of middle names in Jutland is found $(4.7 \%)$, is also among the counties with the lowest urbanity (10.4\%).

Further analysis of the usage of middle names in rural and urban parishes yields conflicting results, suggesting that there may be two distinct processes at work. In counties where middle names occur relatively frequently, they tend to be more common in rural areas than in urban, supporting the hypothesis that these middle names originate from a preservation of traditional naming practice, albeit within a new naming pattern. By contrast, in the counties of Zealand, middle names are slightly more frequent in the urban parishes, which may be indicative of their use as a differentiating marker: people moving from rural areas to towns may have adopted middle names primarily to make themselves more readily distinguishable by name (Kisbye 1979; 1981).

These suppositions have been explored by analysing the backgrounds of those individuals registered with middle names in Copenhagen; here there is some indication of both patterns. It can be seen from Table 3 that migrants from those counties with the highest frequency of middle names tend, when registered in the capital, to exhibit middle names at slightly lower frequencies than recorded in their home county, though still at a frequency higher than the average for city dwellers taken as a whole. The exception is the county Ringkøbing where a pattern similar to what is shown for counties with a low frequency of middle names is found, namely that middle names are more in use among those who have migrated to Copenhagen than those in their home county. It is noteworthy, however, that migrants from the three counties with the highest shares of middle names, Ribe, Thisted and Vejle, are also among the groups with the highest frequencies of middle name usage found in Copenhagen. 


\section{LARS-JAKOB HARDING KÆLLERøD AND BARBARA ANA REVUELTA-EUGERCIOS}

Table 3: The percentage of onomastic profiles containing middle names in the Danish counties and among residents in Copenhagen in C1880 according to their county of origin, as reported as their place of birth in the source. For the area administered by the capital a distinction is made between residents within the city of Copenhagen itself and those living outside (Rest).

\begin{tabular}{|l|r|r|}
\hline County (of origin) & $\begin{array}{c}\text { Middle names: } \\
\text { residents within } \\
\text { the county }\end{array}$ & $\begin{array}{c}\text { Middle names: } \\
\text { residents in } \\
\text { Copenhagen }\end{array}$ \\
\hline Aalborg & $5.2 \%$ & $6.8 \%$ \\
\hline Aarhus & $7.1 \%$ & $5.7 \%$ \\
\hline Bornholm & $6.8 \%$ & $6.7 \%$ \\
\hline Copenhagen & $3.3 \%$ & $2.9 \%$ \\
\hline - City & $3.6 \%$ & $2.9 \%$ \\
\hline - Rest & $2.3 \%$ & $2.9 \%$ \\
\hline Frederiksborg & $2.2 \%$ & $2.4 \%$ \\
\hline Hjørring & $4.7 \%$ & $6.5 \%$ \\
\hline Holbæk & $2.0 \%$ & $2.5 \%$ \\
\hline Maribo & $3.6 \%$ & $5.3 \%$ \\
\hline Odense & $4.0 \%$ & $5.4 \%$ \\
\hline Præstø & $2.2 \%$ & $2.6 \%$ \\
\hline Randers & $10.7 \%$ & $8.0 \%$ \\
\hline Ribe & $15.6 \%$ & $14.1 \%$ \\
\hline Ringkøbing & $10.0 \%$ & $14.1 \%$ \\
\hline Sorø & $1.7 \%$ & $2.7 \%$ \\
\hline Svendborg & $8.7 \%$ & $6.6 \%$ \\
\hline Thisted & $15.2 \%$ & $10.6 \%$ \\
\hline Vejle & $13.1 \%$ & $8.1 \%$ \\
\hline Viborg & $6.9 \%$ & $9.6 \%$ \\
\hline
\end{tabular}

The heterogeneous geographical distribution of middle names and the differences between their currency in rural and urban parishes seem to indicate different reactions to the legislation in different parts of the country; middle names may have a different significance (possibly reflecting different values) for residents of Jutland and Zealand, in towns and the countryside.

\subsection{Sex}

The aforementioned pilot studies (Kællerød 2017a; 2017b) show a significant difference in name usage among men and women, as middle names were registered between three and twenty times more often among males than females. The present survey demonstrates that, on a national level, middle names are borne by $10.2 \%$ of men and only $2.3 \%$ of women. However, as the pilot studies suggested, the differences are not homogeneous across the country, as shown in Table 4. 
Table 4: The percentage of onomastic profiles containing middle names, broken down by county and gender. Throughout Denmark, middle names are much more common among male residents, but by varying degrees; the column on the right presents the factor by which middle names are more frequent among males than among females.

\begin{tabular}{|l|l|r|r|r|}
\hline County & Region & $\begin{array}{c}\text { Men with } \\
\text { middle names }\end{array}$ & $\begin{array}{c}\text { Women with } \\
\text { middle names }\end{array}$ & $\begin{array}{c}\text { Factor of } \\
\text { difference }\end{array}$ \\
\hline Aalborg & Jutland & $8.8 \%$ & $1.6 \%$ & 5.5 \\
\hline Aarhus & Jutland & $11.4 \%$ & $2.8 \%$ & 4.1 \\
\hline Bornholm & Bornholm & $13.2 \%$ & $0.7 \%$ & 19.4 \\
\hline Copenhagen & Zealand & $5.6 \%$ & $1.3 \%$ & 4.3 \\
\hline Frederiksborg & Zealand & $4.1 \%$ & $0.4 \%$ & 10.8 \\
\hline Hjørring & Jutland & $7.9 \%$ & $1.6 \%$ & 4.9 \\
\hline Holbæk & Zealand & $3.5 \%$ & $0.5 \%$ & 7.0 \\
\hline Maribo & Lolland-Falster & $6.3 \%$ & $1.1 \%$ & 5.7 \\
\hline Odense & Funen & $6.4 \%$ & $1.5 \%$ & 4.2 \\
\hline Præstø & Zealand & $3.2 \%$ & $1.2 \%$ & 2.8 \\
\hline Randers & Jutland & $16.9 \%$ & $4.6 \%$ & 3.7 \\
\hline Ribe & Jutland & $27.3 \%$ & $3.8 \%$ & 7.2 \\
\hline Ringkøbing & Jutland & $15.3 \%$ & $4.7 \%$ & 3.2 \\
\hline Sorø & Zealand & $2.9 \%$ & $0.5 \%$ & 6.0 \\
\hline Svendborg & Funen & $15.2 \%$ & $2.3 \%$ & 3.7 \\
\hline Thisted & Jutland & $23.7 \%$ & $7.0 \%$ & 3.5 \\
\hline Vejle & Jutland & $20.3 \%$ & $5.9 \%$ & 3.8 \\
\hline Viborg & Jutland & $10.8 \%$ & $2.8 \%$ & $\mathbf{4 . 5}$ \\
\hline Denmark & & $\mathbf{1 0 . 2 \%}$ & $\mathbf{2 . 3 \%}$ & \\
\hline
\end{tabular}

The proportion of male residents listed with middle names varies from $2.9 \%$ in Sorø County to $27.3 \%$ in Ribe County. The lowest proportion of women with middle names is found in Frederiksborg County $(0.4 \%)$, while the highest is in Thisted County (7.0\%). It is noteworthy that middle names are more common among women in Thisted than they are among men in any of the five counties on Zealand.

The greatest difference between the sexes in middle name frequency is found on the island of Bornholm, where $13.2 \%$ of men have middle names, compared with only $0.7 \%$ of women, with middle names almost twenty times more common among male onomastic profiles than in their female counterparts. The second largest difference is found in Frederiksborg on Zealand, where middle names are 10.8 times more frequent among men than women - a difference almost only half as big as the one on Bornholm. The third biggest difference is found in Jutland, in Ribe county, where middle names are 7.2 times more common among men. The county with the smallest difference, 2.8, is Præstø on Zealand, where middle names occur in $3.2 \%$ and $1.2 \%$ of the onomastic profiles for men and women respectively. 
One explanation for these differences in name patterns among men and women may simply be gender-specific practices in the naming of new-borns, possibly reflecting a patriarchal society where it may have been more important to mark a son's heritage than a daughter's. Life changes may have an impact on the presence of middle names as well, not least among women. Marriage, divorce and widowhood could all affect the names under which individuals are listed in C1880.

Table 5: The percentage of middle names among individuals aged 20 or more in C1880 allocated by marital status.

\begin{tabular}{|l|r|r|}
\hline Marital status & \multicolumn{1}{|c|}{ Men } & Women \\
\hline Unmarried & $9.1 \%$ & $2.0 \%$ \\
\hline Married & $9.9 \%$ & $1.6 \%$ \\
\hline Separated/divorced & $9.8 \%$ & $2.1 \%$ \\
\hline Widowed & $10.3 \%$ & $1.3 \%$ \\
\hline Unknown/Missing & $9.1 \%$ & $1.4 \%$ \\
\hline Denmark & $\mathbf{9 . 7 \%}$ & $\mathbf{1 . 7 \%}$ \\
\hline
\end{tabular}

However, preliminary analysis of middle names among people aged 20 or older ${ }^{9}$ shows no clear relation between marital status and middle name frequency (Table 5). The proportion of women listed as unmarried or separated/divorced is almost identical (approximately 2\%), while middle names are less common among married women and widows $(1.6 \%$ and $1.3 \%$ respectively). For men, the distribution of middle names is almost the opposite as they are most common among widowers (10.3\%) and rarest among unmarried men $(9.1 \%)$. However, the frequency of middle names across different marital statuses is relatively stable and that no distinct anomaly stands out.

\subsection{Age}

C1880 records individuals born between the late 18th century and 1880 , containing onomastic profiles for those born, and first named, under three distinct periods in terms of legislation: those born before the first public name regulations in the Kingdom of Denmark in 1828; those born after 1828 but before the permanent transition to patrilineal surnames in 1856; and those born after the 1856 legislation. Examination of birth cohorts illustrates the development in the usage of middle names over time and provides indications of the relationship between practice and legislative context.

9 To examine the part of the population that actually could be married, people under the age of 20 was excluded. 
However, it is important to remember that $\mathrm{C} 1880$ gives no information as to whether a middle name was given at baptism or adopted at a later stage in life, nor the reasons behind renaming or revised reporting.

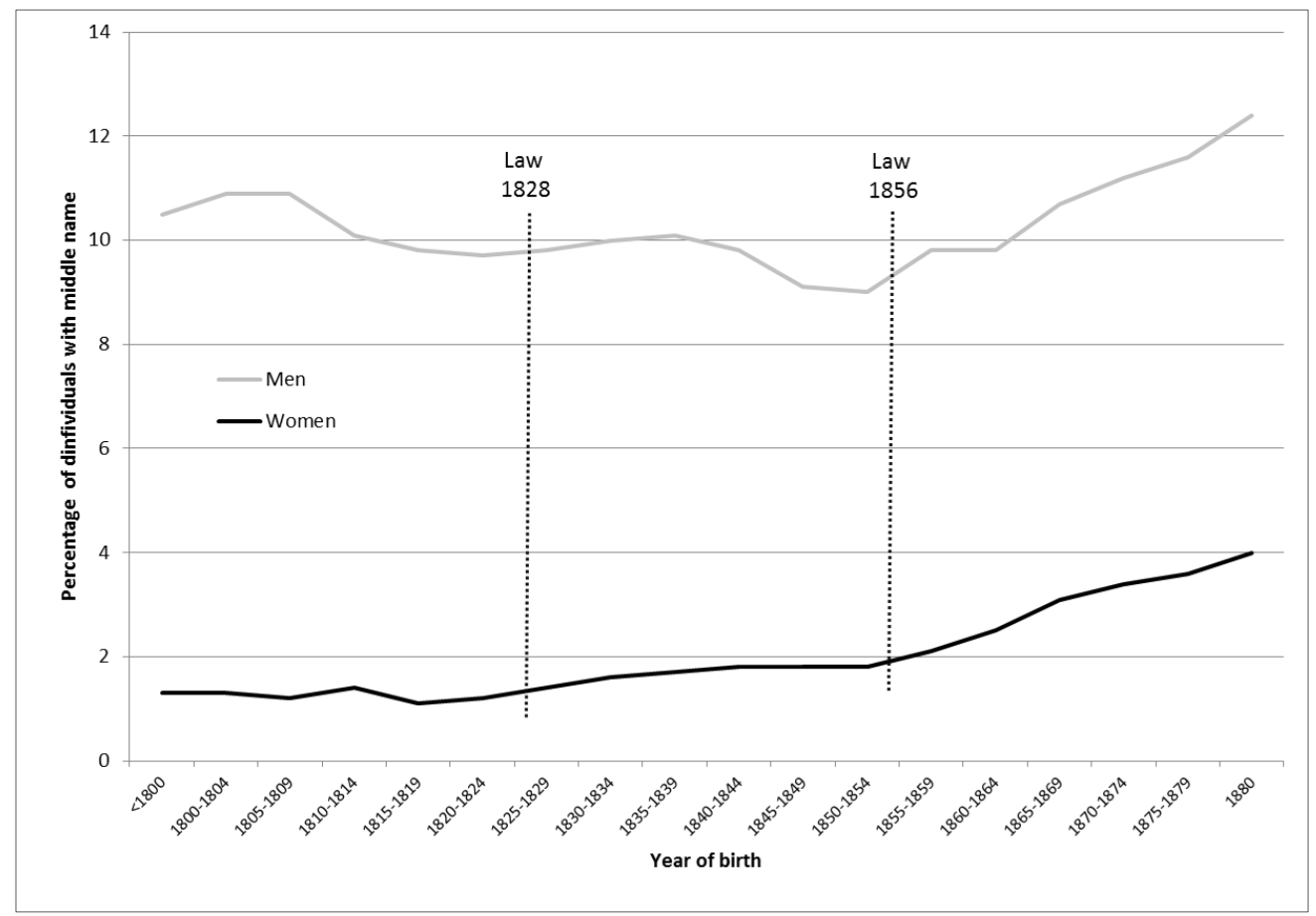

Figure 2: Percentage of onomastic profiles in C1880 containing middle names by year of birth and sex. The vertical lines mark the legislation of 1828 and 1856.

The prevalence of middle names among men and women differentiated by age group, revealing naming trends over time by reference to approximate date of birth (Figure 2). The gender difference in middle name frequency gradually narrows: men from earlier generations are up to nine times more likely to have a middle name than women of the same age; for the younger generation, that difference is reduced to a factor of three or thereby. There is a general trend of increasing use of middle names among individuals aged 25 or under, those born around or subsequent to the 1856 legislation coming into force. The relatively even arithmetic increase in middle names over this period, which translates to an additional 2\% (approximately) of both the male and female population bearing a middle name, has the effect of doubling the total frequency of middle names among women.

The relationship between middle names and name regulations may not be obvious, since Figure 2 peculiarly shows higher proportions of middle names among men born around 1810 or earlier than is the case for those born between 
1828 and 1856 (cf. Table 6). Further, the figure shows that the usage of middle names only had a very limited increase in the period following the 1828 regulations, before a fall to the lowest share of middle names among men shortly before the legal tightening in 1856 (which, unlike the legislation of 1828 , seems to have had a positive impact on the use of middle names).

Table 6: The percentage of onomastic profiles containing middle names in each county divided into age intervals representing: the elder generation of individuals born prior to any name legislation affecting the general population of the Kingdom of Denmark, aged 70-75 (born c. 1805-1810); individuals born between the two legislations, age 40-45 (born c. 1835-1840); individuals born around or shortly after the coming into force of the 1856 legislation, age 20-25 (born c. 1855-1860); and the youngest generation, aged 0-5 (born c. 1875-1880).

\begin{tabular}{|l|r|r|r|r|r|}
\hline County & Age 70-75 & Age 40-45 & Age 20-25 & Age 0-5 & \multicolumn{1}{c|}{ All ages } \\
\hline Aalborg & $7.0 \%$ & $4.7 \%$ & $4.4 \%$ & $6.0 \%$ & $5.2 \%$ \\
\hline Aarhus & $5.2 \%$ & $5.7 \%$ & $6.8 \%$ & $10.2 \%$ & $7.1 \%$ \\
\hline Bornholm & $13.3 \%$ & $8.6 \%$ & $5.8 \%$ & $3.6 \%$ & $6.8 \%$ \\
\hline Copenhagen & $4.1 \%$ & $3.3 \%$ & $3.6 \%$ & $3.3 \%$ & $3.3 \%$ \\
\hline Frederiksborg & $2.0 \%$ & $1.7 \%$ & $2.3 \%$ & $2.9 \%$ & $2.2 \%$ \\
\hline Hjørring & $3.4 \%$ & $4.5 \%$ & $4.1 \%$ & $6.8 \%$ & $4.7 \%$ \\
\hline Holbæk & $1.5 \%$ & $2.0 \%$ & $1.9 \%$ & $2.0 \%$ & $2.0 \%$ \\
\hline Maribo & $5.0 \%$ & $4.5 \%$ & $2.7 \%$ & $3.3 \%$ & $3.6 \%$ \\
\hline Odense & $2.0 \%$ & $3.9 \%$ & $4.7 \%$ & $5.1 \%$ & $4.0 \%$ \\
\hline Præstø & $1.9 \%$ & $2.1 \%$ & $2.0 \%$ & $2.7 \%$ & $2.2 \%$ \\
\hline Randers & $10.9 \%$ & $10.5 \%$ & $10.1 \%$ & $12.3 \%$ & $10.7 \%$ \\
\hline Ribe & $9.2 \%$ & $14.1 \%$ & $16.9 \%$ & $19.5 \%$ & $15.6 \%$ \\
\hline Ringkøbing & $6.7 \%$ & $10.4 \%$ & $9.2 \%$ & $12.7 \%$ & $10.0 \%$ \\
\hline Sorø & $1.8 \%$ & $1.4 \%$ & $1.9 \%$ & $2.1 \%$ & $1.7 \%$ \\
\hline Svendborg & $5.3 \%$ & $9.5 \%$ & $8.4 \%$ & $9.8 \%$ & $8.7 \%$ \\
\hline Thisted & $16.7 \%$ & $14.1 \%$ & $12.7 \%$ & $18.9 \%$ & $15.2 \%$ \\
\hline Vejle & $10.1 \%$ & $11.4 \%$ & $12.1 \%$ & $18.0 \%$ & $13.1 \%$ \\
\hline Viborg & $8.4 \%$ & $6.1 \%$ & $5.1 \%$ & $9.5 \%$ & $6.9 \%$ \\
\hline Denmark & $\mathbf{5 . 6 \%}$ & $\mathbf{5 . 8 \%}$ & $\mathbf{5 . 9 \%}$ & $\mathbf{7 . 7 \%}$ & $\mathbf{6 . 2 \%}$ \\
\hline
\end{tabular}

These various patterns make it problematic to draw conclusions about the name regulations' impact on the use of middle names. In certain counties it is possible that there is a link while in others that cannot be the case.

An explanation of why many individuals in older generations are listed with middle names in C1880 may lie with the traditional naming practice, previously mentioned, of people being known by a first name, an additional patronymic, and a distinctive byname (referring, for example, to skills, features or occupations) known and used within smaller communities. It is not unlikely that older individuals registered in C1880 with onomastic profiles such as Hans Andersen Møller ('miller') or Laurids Nielsen Krøl 
('curly') have regarded such a byname as much a part of their name as the patronymic, and therefore were registered in the census with what appears to be both a middle name and a surname. However, by the time of C1880, many of these last names, though bynames in origin will be at least in the transition of losing their descriptive function, particularly if passed on to subsequent offspring, and thereby acquire the characteristic of family names (cf. Kousgård Sørensen 1975: 112). To confirm this hypothesis, further examinations beyond the scope of this article would have to be made.

\section{Closing remarks}

This article has presented the first evidence of the use of middle names in late 19th century Denmark, as they are recorded in the census of 1880. For this purpose, a methodology has been introduced for identifying middle names from full onomastic profiles. This process is useful not only for extracting middle names but also for identifying every name component in an onomastic profile, leading to a greater understanding of Danish naming patterns. The middle names identified in this process have been analysed to investigate motives for the use of middle names, as well as to study regional variation and certain demographic aspects concerning the usage of middle names. The programme developed to achieve these results has proven reasonably reliable and exhaustive (reaching $98 \%$ of all named individuals) and it offers a promising tool for further examinations of names in Danish historical sources.

Additional work, such as analysis of earlier and later censuses, is required to properly account for reactions to the legislation as well as the practices of changing names over the course of an individual. In spite of these caveats, this article has offered new insights into a staple of Danish onomastics, the middle name. The methodology presented can be scope for further, more qualitative research, to fine-tune of the algorithms used based on the solid work already done in classifying name components by type.

\section{References}

$\mathrm{AO}=$ Arkivalier Online. Folketællinger. Statens Arkiver [Archives online. Censuses. Danish National Archives]. Copenhagen. (https://www.sa.dk/aosoegesider/en/rif/rif-collection/7) (Accessed 2018-01-11.)

BLP 1960 = Betænkning om en ny lovgivning om personnavne, afgivet af det af Justitsministeriet den 20. marts 1952 nedsatte udvalg. Betænkning nr. 254, 1960 [Report on a new legislation on personal names, issued 
98 LARS-JAKOB HARDING KÆLLERøD AND BARBARA ANA REVUELTA-EUGERCIOS

by the committee, set up by the Ministry of Justice on the 20th March 1952. Report no. 254, 1960]. Copenhagen.

$\mathrm{C} 1787=$ The Danish Census of 1787. See AO and DDD.

$\mathrm{C} 1880=$ The Danish Census of 1880. See AO and DDD.

Chambers, J.K. \& Trudgill, Peter. 1998. Dialectology, 2nd edition. Cambridge: Cambridge University Press.

Clausen, Nanna Floor. Danish National Archives. 1880 Census Denmark.

Clausen, Nanna Floor. 2015. The Danish demographic database - Principles and methods for cleaning and standardisation of data. In Bloothooft, Gerrit et al. (eds.), Population reconstruction, 3-22. Cham: Springer. DOI: 10.1007/978-3-319-19884-2

Danskernes Navne [The names of the Danes]. (http://www.danskernesnavne. navneforskning.ku.dk/Personnavne.asp) (Accessed 2018-01-21.)

DDD = Dansk Demografisk Database [Danish demographic database]. (http://ddd. dda.dk/kiplink en.htm) (Accessed 2018-01-11.) (cf. Clausen, Nanna Floor)

DDU $=$ Det Danske Udvandrerarkiv [The migration records in Denmark]. (http://www.udvandrerarkivet.dk/udvandrerprotokollerne/) (Accessed 201801-21.)

Degn, Ole. 2001. De danske efternavne på -sen. Landbefolkningens reaktioner på navnelovene af 1828 og 1856 [The Danish surnames in -sen. The rural population's reactions to the acts of names of 1828 and 1856]. Personalhistorisk Tidsskrift 121, 14-34.

DiplDan = Diplomatarium Danicum 1. -4. series. 1938 ff. Franz Blatt et al. (eds.). Copenhagen.

Dåbsforordningen 1828 = Forordning om Adskilligt som i Henseende til Daaben bliver at iagttage [Ordinance on several things that as regards baptism should be observed]. (https://www.retsinformation.dk/Forms/R0710.aspx? $\mathrm{id}=72643$ ) (Accessed 2018-01-11.)

Eggert, Birgit. 2008. Nordisk navnerenæssance i Danmark [The Nordic name renaissance in Denmark]. In Kvaran, Guðrún et al. (eds), Norrcen nöfn - Nöfn á Norðurlöndum. Hefðir og endurnýjun / Nordiska namn Namn $i$ Norden. Tradition och förnyelse. Handlingar från Den fjortonde nordiska namnforskarkongressen i Borganes 11-14 augusti 2007 (NORNA-rapporter 84), 113-137. Uppsala: NORNA-förlaget.

Eggert, Birgit. 2009. Almuens fornavne omkring år 1800 [Christian names among the Danish rural population c. 1800]. Landbohistorisk Tidsskrift 1, 89-125.

Feldbæk, Ole. 1991. Skole og identitet 1789-1848. Lovgivning og lærerbøger [School and identity. Legislation and textbooks]. In Feldbæk, Ole (ed.) Dansk identitetshistorie 2. Et yndigt land 1789-1848, 253-324. Copenhagen: C.A. Reitzels Forlag.

Hjorth Pedersen, Birte. 1983. Hvad forstås der ved termen mellemnavn? [What is meant by the term middle name?]. In Hallberg, Göran \& 
Isaksson, Stig \& Pamp, Bengt (eds.), Personnamnsterminologi. NORNAs åttonde symposium $i$ Lund 10-12 oktober 1981 (NORNArapporter 23), 78-86. Uppsala: NORNA-förlaget.

Johansen, Hans Christian. 2004. Early Danish census taking. The History of the Family 9(1), 23-31. DOI: 10.1016/j.hisfam.2001.10.006

Jørgensen, Bent. 2013. Det dobbelte efternavn i Danmark før år 1800 [The double surname in Denmark before 1800]. Studia anthroponymica Scandinavica 31, 13-30.

Kisbye, Torben. 1979. »Alfred Dreyfus Nielsen« Identifikationsmodeller i dansk navneskik - belyst ved drengenavne i Århus 1800-1950. [»Alfred Dreyfus Nielsen « Identification models in Danish naming practice - Illustrated by boys' names in Aarhus 1800-1950]. Convivum, 82-107. [Collection of minor articles and pamphlets, Centre for Name Research, Department of Nordic Studies and Linguistics, University of Copenhagen.]

Kisbye, Torben. 1981. Slægtsnavne og patronymer [Family names and patronymics]. Personalhistorisk Tidsskrift, årgang 101, 121-132.

Kousgård Sørensen, John. 1975. Tilnavne og slægtsnavne. Et diskussionsoplæg [Bynames and family names. A discussion paper]. In Andersson, Thorsten (ed.), Binamn och släktnamn. Avgränsning och ursprung. Handlingar från NORNA:s tredje symposium $i$ Uppsala 27-28 april 1974 (NORNA-rapporter 8), 111-127. Uppsala: Nordiska Samarbetskommittén för Namnforskning.

Kousgård Sørensen, John. 1984. Patronymer i Danmark I. Runetid og middelalder [Patronymics in Denmark I. Runic times and Middle Ages]. (Navnestudier no. 23). Copenhagen: Akademisk Forlag.

Kousgård Sørensen, John. 1997. Patronymer i Danmark II. Nyere tid og nutid [Patronymics in Denmark II. Recent times and present times]. (Navnestudier no. 37). Copenhagen: C.A. Reitzels Forlag.

$\mathrm{KVJb}=$ Kong Valdemars Jordebog, bind 1 [Roll of King Valdemar (Liber Census Daniae), vol. 1]. Svend Aakjær (ed.), 1926-43. Copenhagen: Samfund til udgivelse af gammel nordisk litteratur.

Kællerød, Lars-Jakob Harding. 2015. Aktuel forskning. Forskerprofil med præsentation af ph.d.-afhandlingen Adam Gottlob Øhlenschloger Hauch \& Jeppe Smed Jensen. Et studie af etableringen af det efternavnetypologiske mellemnavn i Danmark i 1800-tallet (afleveret, december 2018) på Institut for Nordiske Studier og Sprogvidenskabers hjemmeside [Current research. Researcher profile with a presentation of the $\mathrm{PhD}$ project Adam Gottlob Ohlenschloeger Hauch \& Jeppe Smed Jensen. A study of the establishment of the surname typological middle name in the 19th century Denmark (submitted, December 2018) on the website of Department of Nordic Studies and Linguistics]. (http://nors.ku.dk/english/staff/?pure=en/persons/ 290666) (Accessed 2019-03-08.) 
100 LARS-JAKOB HARDING KÆLLERøD AND BARBARA ANA REVUELTA-EUGERCIOS

Kællerød, Lars-Jakob Harding. 2017a. Det danske mellemnavn: et spørgsmål om identitet? Betragtninger over brugen af mellemnavne i Danmark i 1800tallet [The Danish middle name: A question of identity? Comments about the usage of middle names in Denmark in the 19th century]. In Leino, UnniPäivä et al. (eds.), Namn och identitet. Handlingar från NORNAs 46:e symposium i Tammerfors den 21-23 oktober 2015 (NORNA-rapporter 94), 95-112. Uppsala \& Tammerfors: NORNA-förlaget.

Kællerød, Lars-Jakob Harding. 2017b. Valg af mellemnavne som kilde til forståelse af identifikationsbehov i 1800-tallet [The selection of middle names as a source of information about the need for identification in the 19th century]. In Schmidt, Tom \& Særheim, Inge (eds.), Namn som kjelder. Rapport frå Den sekstande nordiske namneforskarkongresse på Joren folkehøgskule, Kleppe 8. -11. juni 2016 (NORNA-rapporter 96), 117-132. Uppsala: NORNA-förlaget.

Kællerød, Lars-Jakob Harding. 2018a. A distinctive local usage of middle names in Denmark. In Slíz, Mariann \& Walkowiak, Justyna B. (eds.), Proceedings of the 26th International Congress of Onomastic Sciences, Debrecen, 27 August - 1 September 2017 (Onomastica Uralica 13), 135-147. Debrecen \& Helsinki.

Kællerød, Lars-Jakob Harding. 2018b. Sankt Katharina som navngivningsmotiv i Danmark [Saint Catherine as a motive for naming in Denmark]. In Mattfolk, Leila \& Neumüller, Kristina et al. (eds.), Katharina och namnen. Vänskrift till Katharina Leibring på 60-årsdagen den 20 januari 2018 (Namn och samhälle 30), 27-33. Uppsala.

LP 1961 = Lov om Personnavne. Lov nr. 140 af 17. maj 1961. Justitsmin. L. A. j. nr. 73/1960 [Act of Personal Names. Act no. 140 of May 17, 1961. Ministry of Justice. L. A. j. no. 73/1960]. Copenhagen.

Matthiesen, Poul Christian. 1985. The limitation of family size in Denmark, vol. I-II. Princeton European Fertility Project. Copenhagen: Det Kongelige Danske Videnskabernes Selskab.

Meldgaard, Eva Villarsen. 1965. Sydvestjysk navneskik gennem 300 år [Naming practice in Southern Jutland through 300 years]. (Navnestudier no. 4.) Copenhagen: G.E.C. Gads Forlag.

Meldgaard, Eva Villarsen. 1993. Navnemode og modenavne. 6000 drenge- og pigenavne [Name fashion and modern names. 6000 boy names and girl names], 2nd edition. Værløse: Billesø \& Baltzer.

N 2006 = Navnelov. Lov nr. 524 af 24/06/2005 [Act of Names. Act no. 524 of June 24, 2005] (Issued April 1, 2006). (https://www.retsinformation.dk/ Forms/R0710.aspx?id=31494) (Accessed 2018-01-15.)

PBN $2004=$ Personnavne. Betænkning afgivet af Navnelovsudvalget. Betænkning nr. 1446, 2004 [Personal Names. Report submitted by the Committee of Acts of Names. Report no. 1446, 2004]. Copenhagen. 
Pedersen, Karl Peder. 2001. Navnet, det er stadig Jensen. Om danske navneregler og om skiftende tiders muligheder for at ændre navn [The name is still Jensen. About Danish name regulations and about possibilities of changing name in various times]. Personalhistorisk Tidsskrift 121, 200-221.

Revuelta-Eugercios, Barbara Ana. 2016. Studying socio-economic differences in mortality in 19th century cities with individual level data: the Copenhagen Historical Population Databse. In Jørgensen, Lars et al. (eds.), Food, population and health - Global patterns and challenges. Proceedings of an interdisciplinary symposium on the dynamics from prehistory to present, 51-62. Copenhagen: Det Kongelige Danske Videnskabernes Selskab.

Revuelta-Eurgercios, Barbara Ana. (in press). Re(creating) lifecourses from crowdsourced digital data: The challenge of linking the population of Copenhagen in the 1880 and 1885 censuses.

Revuelta-Eugercios, Barbara Ana \& Løkke, Anne. (in press). Dying from diarrhoea or debilitas congenita? Exploring causes of death for illegitimate infants in Copenhagen in the 1880s through the medical death certificates. In Sjöberg, M. (ed.), Health and health care in history.

Vogt, Susanne. 2005. Adelens brug af faste slægtsnavne før og efter Fr. I's forordning af 1526 [The use of fixed family names among the nobility before and after Fr. I's Regulation of 1526]. In Nyström, Staffan (ed.), Namnes dynamik. Utvecklingstendenser och drivkrafter inom nordiskt namnskick. Handlingar från den trettonde nordiska nanforskerkongressen $i$ Tällberg 15-18 augusti 2003 (NORNArapporter 80.), 383-404. Uppsala: NORNA-förlaget. 